\title{
Globalisation and outsourcing: confronting new human resource challenges in India's business process outsourcing industry
}

\author{
Sarosh Kuruvilla \\ School of Industrial Relations, Cornell University \\ Aruna Ranganathan \\ Doctoral Candidate, Sloan School of Management, MIT
}

\begin{abstract}
In this article, we argue that the rapid growth of the outsourcing industry has resulted in both high turnover and labour shortages and at the same time provided employment opportunities to a new group of employees: young upwardly mobile college graduates. We argue that this particular demographic profile is prone to high turnover and presents new managerial challenges. We then examine the variety of recruitment and retention strategies that companies in the business process outsourcing industry are experimenting with and show that many novel HR strategies are being crafted to address the needs of this young middle-class workforce. We also examine macro efforts by state and central governments and the industry association to help resolve some of these problems.
\end{abstract}

\section{Introduction}

It is well established that globalisation, particularly in terms of the mobility of capital and the spread of communication technologies, has had a profound effect on employment relations in countries that are well integrated into the global economy. The rapid increase in service sector 'outsourcing' and 'offshoring' during the last decade has created a new and rapidly growing 'business process outsourcing' (BPO) industry in India. While this industry has experienced phenomenal growth rates and has contributed significantly to India's export earnings, it has also thrown up new employment relations challenges.

At the level of the firm, the challenge is to manage a new breed of employees: young, middleclass, 'upwardly mobile' college graduates (who form the bulk of employment in this industry) who historically have not played a significant role in the labour market at their age (prior to the growth of this industry, middle-class college graduates would normally have continued onwards for postgraduate 
qualifications before entering the labour market). At the level of the economy, the challenge is to solve the problem of adequate supply of skilled labour, one that contributes to record high levels of turnover and rapidly increasing costs that are a threat to the long-term sustainability of the industry.

This article traces the growth of the BPO industry in India and argues that the demographic profile of employees in the industry contributes to rising turnover but also presents Indian HR managers with particular challenges in attracting and retaining employees. We then highlight the variety of strategies that firms are experimenting with in responding to these challenges.

The research in this article is the result of five months of intensive fieldwork across the metropolitan cities in India conducted in 2004 as part of a larger research project on outsourcing. That fieldwork included extensive interviews with a sample of $20 \mathrm{HR}$ managers of BPO firms that was the primary source of information for this article. In addition, follow-up interviews were conducted with a second sample of eight HR managers from larger BPOs who were attending a conference on HR issues sponsored by the National Association of Software and Services Companies (NASSCOM) in the summer of 2007. The two sets of interviews, along with some participant observation of the flow of BPO work in four BPOs and some archival research and regular reading of the 'trade' journals, provided the basis for our argument in the article. Given that the companies that we interviewed were the larger BPOs, with most of them having at least 500 employees, our article might reflect a large company bias.

In the section below, we briefly describe the profile of the industry and its new workforce, and in later sections, we identify key HR problems and describe employer and public policy responses.'

\section{India's Business Process Outsourcing Industry}

India enjoys a dominant position in the global market for business process outsourcing-a 48-50 per cent market share (The Economic Times, 2007). Growing at an annual average rate of over 50 per cent since 1999, this industry has seen employment rise from 50,000 in 1999-2000 to 553,000 by mid-2007. Table 1, which reports basic industry data for the outsourcing industryii, shows that the BPO industry is growing very rapidly (columns 5 and 6). The BPO segment was valued at $\$ 9.5$ billion in 2006-07 and contributed $\$ 8.4$ billion of the outsourcing industry's total exports of $\$ 31$ billion. By 2012 , the BPO segment is expected to overtake the software services segment in terms of overall value (Ranganathan and Kuruvilla, 2007).

Although typified by call centres, the BPO industry is actually a highly variegated industry. Many firms engage in 'low-end' 'services' (involving low skill) such as insurance forms processing and customer service call centres, but there is a discernible and growing 'high-end' services outsourcing market that 
involves very advanced skills (of which many are in short supply). The variability in 'service lines' in the BPO industry is great, and there is a mushrooming of new service lines on almost a weekly basis, making accurate categorisation of the work in the BPO industry difficult. However, in Table 2, we provide a listing of the variety of service lines for which NASSCOM (the industry association) has been collecting data, while we discuss current and newly emerging service lines below.

Customer care and support services for a number of different industries comprise the largest service line, accounting for almost 40 per cent of the industry's employee base and a third of its revenues. Typical examples include customer care for airline reservations, credit card companies etc. (all of which involve direct telephonic contact with the customer). In contrast, a BPO company that focuses on forms processing (in insurance or tax) does not require any contact with the customer and also does not require well-educated English-speaking workers. The finance and accounting service line includes the standard business processes of transaction management, general accounting, statutory reporting, and compliance work while the payment services line includes a variety of billing services, insurance claims processing and tax processing. The HR outsourcing service line is experiencing rapid growth-this typically comprises payroll and benefits administration, travel and expense processing, and employee communication services. In addition, there is a growing 'medical and legal transcription' service line. New service lines involving very high-skilled work have emerged recently, especially in the financial sector (e.g. analysis of financial data, management of foreign commodity accounts, as well as lower-end services such as processing home loans and mortgage services, debt collection and recovery), medicine (creating medical education databases and doctors desk reference guides, but more recently, reading and analysing patient $\mathrm{X}$-rays), printing (pre-publication of scientific journals) and remote education (such as providing math tutorials to US school children), leading to new 'service line' categories known as financial process outsourcing and knowledge process outsourcing (KPO) (Kuruvilla and Ranganathan, 2008).

Engineering services outsourcing is another important line in which India has 15 per cent of the worldwide market share according to a recent study (see NASSCOM, 2006). R\&D outsourcing, too, is growing particularly in two industries: life sciences and finance. 
Sarosh Kuruvilla and Aruna Ranganathan

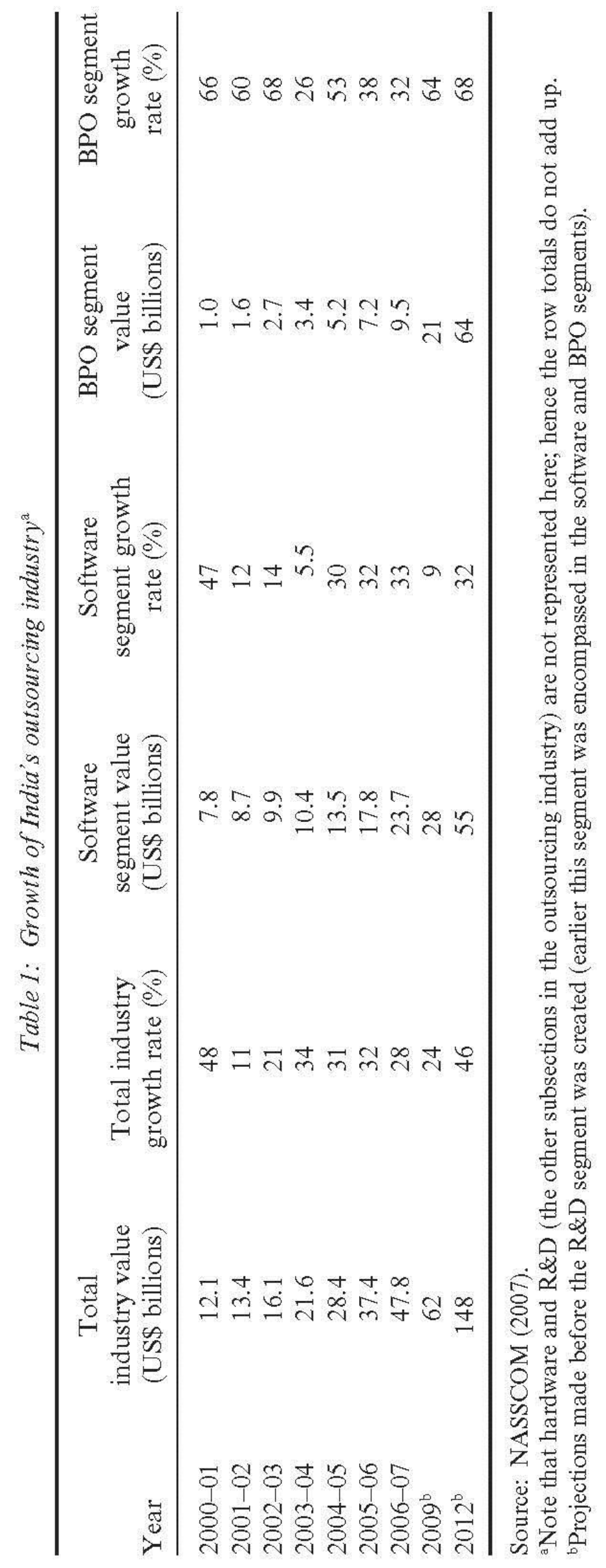


Globalisation and outsourcing

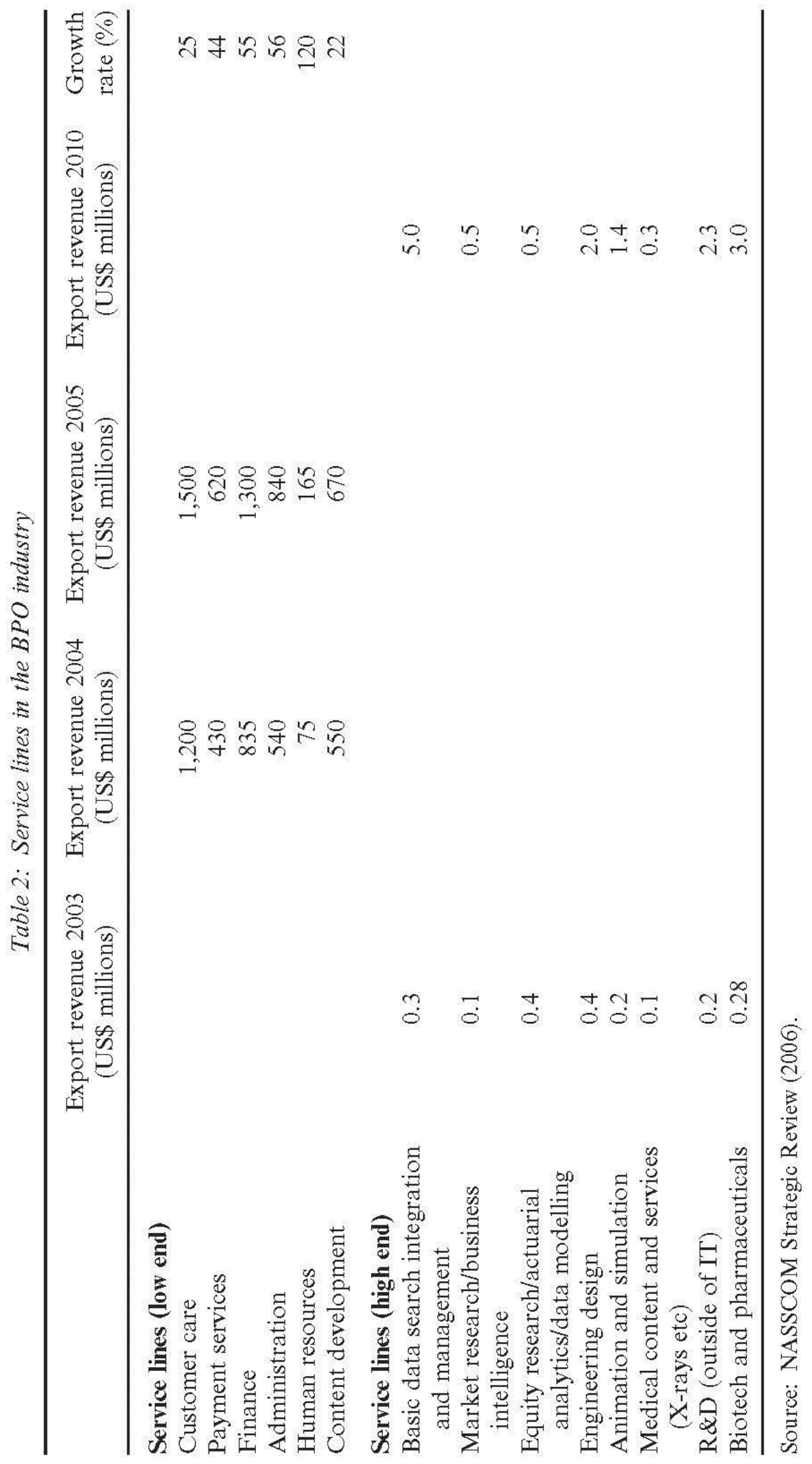




\section{Profile of employees}

The nature of the employees (in terms of their skills distribution) should vary in accordance with the nature of the work done in the BPO industry. For example, a company such as Prodapt deals primarily with forms processing, a low-skill activity. According to their HR manager, they largely hire students who have completed their ' +2 ' (secondary school education) but have not entered college, but also focus on hiring older married women and handicapped people. Typically, their employees tend to be from the 'lower middle class' (interview, Nupur). The profile of employees in BPO firms that provide a range of services in the customer care arena (especially call centres for client firms from the United States and the UK that demand a working proficiency in English) is quite different from those at Prodapt. As Remesh's (2004) survey suggests, 75 per cent of workers in this type of BPO firm are graduates, educated in convent schools (noted for their superior and English-based education). 94 per cent of their fathers and 63 per cent of their mothers were also graduates, many of them working for the government. These employees are drawn from the 'upper classes'. A BPO firm called Aptech, for example, provides content development for companies such as Thompson and McGraw Hill's online and distance education courses. According to the founder of this company, the skills required in this type of BPO are varied, including postgraduates who are computer programming and language experts, postgraduates who act as tutors for various online courses, and graduates to correct exams and provide customer service to online students. This workforce tends to be drawn from the English-speaking middle (middle to upper middle) class and is highly educated (interview, Suresh). At the higher-end KPO level of work, most employees have postgraduate and/or doctoral qualifications.

The prototypical BPO firm therefore employs a largely young middle class cross-section of India's population, often well versed in English. The age ranges from 18 to 24, while the average age at firms employing postgraduates tends to be in the mid-20s. Note that the average wage at a typical BPO firm is around Rs. 12,000 per month (which is about $\$ 300$ or 200 pounds). Prior to the advent of the BPO industry, young middle-class graduates would have found it impossible to find a job paying so much soon after finishing a basic undergraduate degree, and most would have gone for a professional qualification before entering the job market. For middle-class employees who live with their parents, this earning capacity represents a massive increase in 'disposable' income. However, this profile of employees also suggests several peculiar problems that require managerial attention.

In the section below, we highlight two particular human resource problems that the industry has to deal with. These include the very high levels of turnover and the diminishing supply of skilled 
graduates for the industry, both of which threaten industry growth. The turnover problem is primarily within the control of firms, while resolution of the supply of skilled labour problem requires concerted action on the part of several actors in the labour market: state governments, the central government, the industry association, labour market intermediaries, as well as individuals to create a stable skills equilibrium. We are focusing here on the average BPO firm (not those in highly specialised niche markets that employ only postgraduates). Note, however, that turnover and skills shortages are a general problem in India's 'outsourcing' industry, including the much larger 'software services' segment. In the section following this one, we highlight how firms are dealing with these issues.

\section{Human Resource Problem 1: Employee Turnover}

A wide variety of turnover estimates are currently available. Most reports talk about an average of 3040 per cent (per year). Commercial and popular reporting tends to focus on the extremes (the range here is between 12 and 90 per cent). A 2004 study of turnover in seven large 'third-party' call centres showed a wide variation in turnover rates, ranging from as low as 12 per cent to as high as 62 per cent, with a mean turnover of 30 per cent (Remesh, 2004). A key challenge for future research is to explain why there is such a great variation in turnover across firms in the industry. We have some preliminary ideas regarding the factors causing such variation, but our fieldwork is not yet complete. For example, we know that turnover in 'captive' BPOs is typically much lower than in 'third-party' BPOs. iii In our fieldwork, we found turnover rates in five captive firms being between 15 and 20 per cent.

There is job-based variation in turnover as well. Average turnover in 'voice-based processes' is between 45 and 50 per cent, while in 'non-voice' operations, it is 15-20 per cent. Further, 'infant mortality' (turnover in the first 45 days of employment after training) in voice-based processes is about 20 per cent (although anecdotal evidence suggests that this figure may vary to a significant extent). We also know that the type of work the BPO is engaged in and the attendant demographic profile of employees matters, as do efforts by corporations (which we discuss later). For example, Infosys BPO, which has many voice-based processes serving the US market and employs mostly 'well educated young middle class graduates' experienced turnover levels that range between 27-28 per cent and 4045 per cent in 2006-07 (interview, Samit). On the other hand, Prodapt and Laserwords, engaged in forms processing and in preproduction work for the printing and publishing industry, respectively, report turnover rates as low as 6-10 per cent, and they tend to employ people who have finished high school and not gone on to college (interviews, Nupur and Anthony). 


\section{Causes of turnover}

Although there have been no systematic studies regarding the causes of turnover in the outsourcing industry, our research, based on our interviews with HR managers, reveal the following two general categories of causal factors.

Job-related reasons

An important cause here stems from dissatisfaction with the immediate supervisor (the 'lousy boss syndrome'). Because the BPO industry is just five years old, employing mostly young people between the ages of 19 and 27 and experiencing high turnover, often young people with only six months of BPO experience are promoted as supervisors of teams of 10-15 people. There is relatively little time spent on training these people to be effective managers and leaders of people. To add to this, top-down methods dominate companies' staff communication systems (NASSCOM, 2003). These middle managers do not have the required experience to manage teams of young people who themselves do not have a history of work experience and who bring a variety of expectations and aspirations with them when they enter the industry. HR managers refer to this as the 'managerial bandwidth' problem and liken it to the problem of trying to create a '10 years old scotch in 2 years'.

A second key job-related problem lies with the nature of the work itself. Taylor and Bain (2005) observe that 50 per cent of those who exit a call centre leave the industry altogether. There is considerable agreement in international research (Batt et al. 2006; Deery and Kinnie, 2004) that call centre jobs are organised in a 'tayloristic' fashion: highly repetitive, with tightly regulated lunch and restroom breaks, targets in terms of number of calls to be made and a very high degree of monitoring of employee activity. Indian call centres are apparently no different (Remesh, 2004; Taylor and Bain, 2005). A number of articles on coercive and normative control and 'sweatshop practices' in Indian BPO firms are emerging almost daily (see D'Cruz and Noronha, 2006a). These aspects, in combination with working on the night shift (to service the US market by day) has resulted in an outgrowth of what the industry calls burnout stress syndrome, an important cause of turnover. There is growth in the number of employees seeking counselling services and psychological help, and there is an increase in the number of organisations (including trade unions) offering such help. The Young 
Professional Collective in Mumbai, for example, is organised by a well-known labour lawyer and staffed by well-known labour activists.

Third, there is a widespread expectation that there are limited avenues for career advancement in a BPO firm (although the shortage to some extent alleviates this problem). This is supported by our own research and other available evidence. Batt et al.'s (2006) survey of 60 call centres revealed that 15 per cent of call centre workers were promoted to higher positions within the call centre organisation, but only 1 per cent of call centre workers were promoted to upper management levels beyond the call centre section of the organisation. Our research suggests a more nuanced picture: captive call centres are able to provide more promotions to higher levels than 'third-party' call centres because the market stability that 'captive' call centres enjoy permits the envisioning of longer career paths relative to 'thirdparty' call centres.

Thus, dissatisfaction with supervisors, working conditions, the intrinsic aspects of the job itself, and the apparent lack of career advancement prospects abound in the BPO industry, although there is a high degree of pay satisfaction.

\section{Demographic profile of workers}

A number of demographic features contribute to turnover as well. First, many female employees leave the labour force to get married and have children. Second, many young employees 'mark time' in this industry to save some money before going on to graduate school or to better jobs. Third, young employees are willing to move from organisation to organisation (using exit instead of voice) for the smallest possible reason, including a very minor increase in pay or a slightly different office atmosphere, because they do not really see a long-time career with the industry. Such lateral movement is easy given the shortage of trained people in the industry and the clustering of BPO firms in major metros. Fourth, there is the category of 'psycho-social' factors: young people find working in the night shift alienating as they are not able to meet their friends in the evenings or see their families. By the time they get home, other family members have gone to work. Fifth, some face 'dissonance' from a number of sources such as parental disapproval. Pradhan and Abraham (2005) argue that using a different name and adopting a different persona during work hours can cause questioning of one's identity and can lead to what they term the 'multiple personality disorder'. For example, Anjali becomes Angie during the night and talks with an American accent to American customers. This apparently leads to cultural self alienation and a sense of dissonance (see D'Cruz and Noronha, 2006b for an argument regarding how the different name 
helps people deal with some workplace issues). Given these factors and the shortage of adequately trained people, the preference for the use of 'exit' strategies rather than using voice mechanisms (representative organisations such as trade unions are largely absent) is not surprising.

\section{Human Resource Problem 2: Shortage of Appropriately Skilled Labour}

For the prototypical BPO, well-educated, English-speaking 'manpower' has been the key source of competitive advantage. This large HR 'pipeline' has been prized by clients and has contributed to the Indian firms' reputation of being able to 'ramp up quickly' (Raja, interview, 2005). However, there are critical labour shortages in the BPO segment (see The Economic Times, 2006). The BPO segment currently employs 553,000 people directly, growing from a total of 415,000 in $2005-06$. Estimating future demand in this industry is problematic, given the rapid growth rates (50 per cent average annually), the increasing interest in outsourcing in the West and the expansion of India's outsourcing 'footprint'. iv A NASSCOM-McKinsey study projects that there will be a stock of 1 million jobs by 200809, while a NASSCOM-KPMG study forecasts a stock of 1.41 million by 2009 . To the extent that past growth is an indication of future growth (at least in the next three years), the above estimates seem reasonable. After taking into account the current available pool, the annual intake, productivity improvements and current rates of turnover, the KPMG study estimates a shortage of 262,000 people by 2009.

Table 3: Estimates of HR supply for low-end BPO segments 2005

\begin{tabular}{lc}
\hline Output of graduates (253 universities and 13,150 colleges) & $2,460,000^{\mathrm{a}}$ \\
Some English-speaking capability (30\%) & 738,000 \\
Labour force participation (65\%) & $480,000^{\mathrm{b}}$ \\
Effective English-speaking ability for employability in call centre (50\%) & 240,000 \\
Effective supply of labour in 2005 & $168,000^{\circ}$ \\
\hline
\end{tabular}

Source: Kuruvilla and Ranganathan (2008)

anstitute of Applied Manpower Research.

${ }^{\mathrm{b}} \mathrm{NASSCOM}-\mathrm{KPMG}$

'This figure appears to gel with those obtained from our interviews with human resource managers (who already claim that there is saturation in the English-speaking market). The figure is also consistent with another recent estimate that 5-10 per cent of the total graduate pool (between 123,000 and 246,000 people) speak English and are available to work in the industry.

There are no readily available data (published or otherwise) regarding the supply of English-speaking graduates (particularly important for customer service jobs) to the BPO segment. Two problems make accurate forecasting difficult here. The first is the absence of good statistics regarding 
the output of graduates generally, ${ }^{\text {vi }}$ while the second and more critical problem is the difficulty in estimating the number of English speakers available for the BPO call centres. Most human resources managers we talked with tend to feel that the shortfall will be much greater than estimated by NASSCOMvii, probably because of differential estimates of available English-speaking graduates. Table 3, which shows my own estimates of HR supply for the low-end BPO industry, suggests that there is a pool of 250,000 graduates who are potentially available for work in this industry. Making provision for various 'unaccountables', it may be more conservative to put the supply estimate at between 150,000 and 200,000. Not all of these are capable of being hired, though (as recruitment conversion factors are typically in the 2-4 per cent range, that is, firms hire only 2-4 of 100 applicants). And given that the annual intake into the BPO segment is about 120,000 and growing, a shortage of 262,000 bodies (without attention to quality, purely based on whether they can be hired or not) by 2008-09 is a certainty. The high turnover rates are not entirely a function of current shortages, however.

Beyond the shortage of English-speaking bodies, industry representatives highlight shortages in 'industry-ready', 'industry-relevant' manpower, that is, a scarcity of professionals who are equipped with the necessary 'domain' knowledge to cater to specific 'verticals' (industry segments) such as banking, insurance, telecom, retail and manufacturing (Mitra, 2004). And there are shortages in the supply of foreign language skills, notably in French, Spanish, Mandarin, German, and Italian, which makes it difficult for Indian BPOs to expand their presence in European and Asian markets (Indian BPOs derive 82 per cent of their business from the United States and the UK).

Note that the high levels of turnover interacts with the shortage to also increase employee costs rapidly (these have been growing at about 10-15 per cent per year over the last five years). Fortunately, the increases in costs have been more than offset by reductions in bandwidth prices. But the sheer shortage of people implies that India is losing some opportunities as firms unable to hire employees look elsewhere (particularly the Philippines, South Africa and China) to locate their offshore service operations. And many Indian firms too are outsourcing some of their work to these locations.

\section{Confronting Human Resource Problems}

\section{Firm-level responses}

Indian BPO firms are experimenting with a variety of strategies to deal with the turnover problems as well as labour shortage issues. As we discuss below, attempts to solve the turnover problem reflect a 
variety of strategies, some traditional, that is, generally used in most industries, and some specifically designed to suit the demographics of the workforce, that is, young, educated people.

\section{General approaches}

The traditional approaches include a variety of strategies that are consistent with the voluminous prior research on alleviating turnover. First, to counteract the perception that BPO jobs do not offer career growth, employers are investing considerable efforts in articulating career growth opportunities. One widely used strategy is job rotation where employees are trained in a variety of jobs within the BPO (both to relieve monotony and to develop human resources). Incorporating lateral movements in vertically oriented career plans thus meet both individual and organisational needs. Most companies have begun to develop and publicise specific career paths while ensuring that a high percentage of management positions are filled by promotions from within. At GAVS, a small BPO, career planning is taken very seriously and onsite placements, promotions, and skills training for all employees are planned close to a year in advance, giving the employees a sense of stability (interview, Sridhar). Second, allied to career development, BPO firms are also investing heavily in leadership training. While the motivation here is clearly one of self-interest, that is, firms would like to increase 'managerial bandwidth' (and thus simultaneously reduce turnover), there is an element of development and longerterm career planning here that is of mutual interest to both the employer and the employee. From the employer's perspective, leadership development is key to establishing a strong middle management cadre but also increases the loyalty of employees who go through the training. From the employee's perspective, management training complements the career development process and binds the employee more closely to the organisation in the longer term. At Take Solutions, a BPO in life sciences, leaders are identified early on among the entry-level employees and accelerated career paths are made available to them (interview, Sri). Solving the low 'managerial bandwidth' problem justifies the focus on leadership, but in many companies, leadership training is supported in other ways too. Infosys, for example, is training leaders but also making sure that they can practice leadership effectively by reducing spans of control to 1:15 rather than 1:30 (interview, Samit).

Then, there includes some attempts to counter the repetitive nature of work in the call centres. One strategy is to outsource 'boring' work like data entry and seasonal work to smaller companies so that their employees get to do high value-added work. This way, BPO operators get to work on new technologies. This is not possible in all cases, but the principles are transferable. According to the HR 
manager at Infosys BPO, they rank both the projects they receive as well as their employees in order to assign 'Tier 1' workers to the most interesting projects with the hope that the right fit will reduce turnover (interview, Samit).

Finally, some firms have paid attention to the work environment and employee voice. LaserWords, for instance, spends considerable time and effort in crafting ergonomic work spaces with adequate lighting, noise controls, and the creation of a democratic organisational culture that is participatory, with workers being able to exercise voice through a variety of institutional mechanisms. To this end, they have 'maintained a flat organizational structure with no middle management so that employees feel comfortable approaching VPs with any concerns' (interview, Anthony). This partly accounts for their lower turnover rates. Microland, a BPO in remote infrastructure, has also consciously cultivated an 'open-door policy' where entry-level employees mingle with senior management freely (interview, Sowjanya).

Other traditional methods of dealing with turnover such as good pay and benefits (which do not vary much across the industry for similar jobs) and good human resource management practices (which varies quite a lot) in the industry continue to exist. Indian BPO firms are also engaged in a number of other strategies such as targeting older workers who might be more willing to see this as a long-term career and creating new channels of communication with their employees.

\section{Novel strategies geared to workforce demographics}

These strategies reflect an effort by firms to tailor policies specifically to the needs of the particular demographic profile, the young middle-class workforce. First, given that many young people see BPO jobs as a stopgap between graduation and applying for postgraduate qualifications, BPO firms are trying to provide higher education opportunities tied to their employment. This is a risky strategy because they are providing access to educational opportunities that will almost certainly result in the employees leaving after they complete those opportunities. At best, these efforts will result in prolonging an employees' decision to leave by about two or three years. On the other hand, the 'war for talent' is so acute that even two or three years of stability in terms of reduced turnover is important in this extremely 'tight' labour market.

At Microland, there are tie-ups with the prestigious Indian Institute of Management (Bangalore) where Microland co-designs a programme suitable for their employees. Fifty per cent of the course fees are borne by the company to encourage employees to avail of this option while ensuring that employees 
still put effort into the course. The courses last 12-18 months and the hope is that the employees will grow and the company will be able to retain them. However, Microland also institutes a one-year bond once employees have finished their course, during which time employees are not allowed to quit (interview, Sownjanya).

Second, a key development is the recent focus of several BPOs in positioning themselves as 'fun' places to work in order to retain their predominantly young workforce. The goal of these activities is to create an ambience in which the educated and middle-class workforce will enjoy the work atmosphere and hopefully will not leave. As the founder of SSI, a BPO, suggests, 'We make sure to communicate the message that work is serious, work is light and work is fun' (interview, Suresh). Thus, BPOs are increasingly setting aside a budget for 'fun' so as to keep their employees 'happy', coordinated by a new cadre of 'fun officers'.

Creating a balance between work and fun in the workplace requires a significant organisational commitment. There is focus on the physical environment, with BPOs making sure that their physical layouts appeal to their trendy workforce. According to the HR manager at Laserwords, 'The workplace or workstation is given lots of importance at LaserWords as comfort of working is a priority. We use bright colours as much as possible and our chairs are ergonomically designed' (interview, Anthony).

Similarly, there is a focus on recreational facilities that appeal to the workforce. For example, Infosys's campus houses a state-of-the-art gym, golf course, sauna, swimming pool, lake with paddling boats, pool tables and ping pong tables (interview, Samit). Food is also an important aspect of the environment. The Infosys campus contains food courts that serve Chinese, North Indian, South Indian and Western cuisine (interview, Samit). Then there is the focus on wellness. The negative aspects of the call centre environment including night shifts, sedentary work, talking on the phone for hours together and their associated ailments are now well known. Therefore, specific initiatives are being taken by some BPOs to address nutritional and stress-related concerns that employees might have. For example, Prodapt offers yoga classes six days a week to help employees achieve work-life balance (interview, Nupur). To complement the physical attributes of the workplace catering to the young is a focus on an informal atmosphere at work. Many BPOs try to keep the work atmosphere quite informal so that employees loosen up, feel comfortable and have fun at work. With this in mind, Wipro Spectramind has no dress code. And there is a focus on 'fun-filled activities' at the workplace. At Prodapt, an Annual Fun Day is held and preparations for this start 10 days in advance. Events on this day include rangoli competition, flower arrangement competitions, skits and fancy dress competition, birthdays of employees as well as Christmas and other festivals are celebrated at Prodapt too (interview, Nupur). At 
Microland, employees look forward to the end-of- the-week Thank God It's Fridays get-together with pizza and beer (interview, Sowjanya).

And after work, there are parties sponsored by many BPOs at a nightclub or a discotheque, with unlimited food and drink. BPO workers enjoy this immensely as It legitimises partying by making it 'official' and therefore allows them to elude late night curfews imposed by strict parents. Further, BPOs organise regular outings for their employees to bond with one another and with their company outside of work. For example, at LaserWords, once a year a picnic is organised, the most recent one being to Munnar (interview, Anthony). Third, a key new element is the effort to integrate the employee's family into the enterprise in some way. The underlying notion here is that if the family is engaged, then there is greater likelihood of employee retention, as the employee's family is also in some way 'embedded' in the organisation. This is also a response to middle-class family disapproval of BPO careers. Infosys BPO and Transworks have instituted periodic family days that serve as an educational experience for family members as they learn about the various facets of life in the BPO industry and are introduced to team leaders. At Microland, when new employees are hired, the company organises family days where presentations are made to show parents what the work is about as this reduces pressure on the young, new employees (interview, Sowjanya).

Integrating the family at the time of hiring is also common. Accenture's BPO arm has reengineered its hiring process to involve employees' families right from the interview stage to the postrecruitment phase. During the advanced stages of an interview, the company asks the prospective candidate to bring his or her family or spouse along. And specifically geared to retention, many BPOs offer family rewards for longer service. Infosys BPO offers insurance packages for the family (interview, Samit). GAVS organises picnics and get-togethers for employees and their families (interview, Sridhar).

There is also the notion of work-family balance, a response to the problems expressed by young people. For example, at Wipro Spectramind, there are times when an employee needs temporary leave from work when his or her partner has been posted abroad. Such requests are accommodated as far as possible. When a husband and wife pair works for Wipro, the company tries to ensure that both of them are always placed at the same location.

In summary, BPO firms are experimenting with a variety of approaches to control turnover. At this point in time, we do not have any good cross-sectional data to determine which class of approaches work better than others in helping control turnover. On the one hand, high levels of turnover reflect a general shortage of skills. On the other hand, some firms experience lower turnover than others. We know, for example, that at Sitel, the attrition rate is down to 30 per cent from 37 per cent in just eight 
months as a result of the part-time educational opportunities (Shrinate, 2004). Also, we are told that the novel strategies at 24/7 Customer has reduced 'infant mortality turnover' to less than 2 per cent (Menon et al., 2004). As a result of Motif's fun-at-work strategies, 97 per cent of Motif employees said in the same Dataquest- IDC survey that they 'look forward to coming to work.'

However, there is some recent evidence of disillusionment with these novel strategies as well. According to the HR manager at Infosys BPO, 'Fun doesn't create engagement with the company-fun can only help if done simultaneously with the core HR functions' (interview, Samit). Also, the HR manager at Microland said, 'Fun culture helps but it isn't a differentiator-in order to be successful, a differentiator is needed!' (interview, Sowjanya). The founder of TakeSolutions echoes this sentiment: 'the fun culture etc. is "hygiene factors" which the company has to fulfil' (interview, Sri).

Finally, some BPOs are also making small but noticeable attempts at trying to increase the pool of skilled workers available to the BPO industry. Infosys BPO, inspired by their sister organisation Infosys Technologies' initiative, now has a programme called Genesis that trains professors in arts and science colleges in second-tier cities in soft skills such as communication, problem solving, team building etc. (interview, Samit). These professors then conduct workshops for students in their respective colleges, thus creating 'industry-ready' students who are also enthusiastic about entering the BPO industry. Similarly, Microland is trying to promote an ITES special curriculum in schools and colleges for all students interested in the industry (interview, Sowjanya).

\section{Macro-level responses: governments and industry association}

\section{Central and state government}

Governments have a significant role to play in creating skills equilibria (Kuruvilla et al., 2002). Specifically, the problem in the BPO industry is the supply of skilled labour. Governments could, for example, introduce courses of study in government funded universities and colleges that are relevant to industry needs and provide incentives for the private sector to enhance language and communication skills for the industry (the industry has demanded this for quite some time). State governments with large BPO clusters have been more responsive than the central government in this regard (e.g. West Bengal, Orissa, Kerala, Karnataka and Andhra Pradesh), although their efforts are preliminary and variable. The West Bengal government, in association with NASSCOM and the Confederation of Indian Industry, is providing a platform to facilitate exchanges between representatives from the information 
technology (IT) industry and academia. Because industry is the end-user of the human resources, the government feels that it should have more say regarding the curriculum and the process of delivery in colleges and universities. In this way, universities also become aware of the needs of the industry to churn out readily employable professionals. The government of Orissa, realising that there's a dearth of graduates with expertise in IT and proficiency in English, has started a training programme in collaboration with Bangalore Bangalore-based BPO companies like MA-FOI and NEXT (InfotechOnline, 2004). viii

Governments could also assist with reducing both recruitment and training costs for the BPO industry by screening college graduates for their readiness to be part of the IT-ITES industry. Some state governments have introduced various assessment tests to test for industry 'readiness', helping streamline the flow of college graduates to the BPO industry. The government of Karnataka has introduced an aptitude test called the BPO-SAT or BSAT to measure verbal and analytical skills, which is administered through a private service provider called MeriTrac (KPMG, 2004). Similarly, the government of Andhra Pradesh has introduced a Graduate Employability Test (GET) that specifically caters to certification for the IT-ITES industry (KPMG, 2004).

Focusing on the low-cost BPO industry, state and city governments have a key role to play in reducing transportation costs by improving the public transportation infrastructure. Providing safe, reliable public transportation would reduce about 40 per cent of human resource costs in the low-end BPO industry (for more details on the transportation costs incurred by BPOs, see Ranganathan and Kuruvilla, 2007).

For both the KPO and software sectors, governments have a significant role to play in developing long-term high skills human resource capability. The central government and its various agencies have considerably more to do in terms of improving the higher education infrastructure to produce more highly-skilled and doctoral-level researchers, scientists, engineers, and postgraduates in a number of different disciplines for the knowledge processing and R\&D segments. In short, governments must create the 'self-sustaining high skills eco-systems that are found in Silicon Valley (a model for Bangalore and Hyderabad as Saxenian, 2000 notes), the Boston high technology Corridor, Cambridge (UK) and the 'high mech' clusters in Emilia Romagna in Italy (Finegold, 1999; Locke, 1996). The key challenge for governments is to improve second- and third-tier institutions to train students, do more research, attract better faculty, and establish symbiotic ties with the industry, following the pattern of the first-tier institutions (such as the IITs). This will require a complete re-evaluation of a heavily 
entrenched higher education establishment to produce high-quality professors, high-quality students and better research. ${ }^{\text {ix }}$

\section{Industry association}

NASSCOM has been more proactive in taking a longer-term view regarding skills development for the outsourcing industry, although unlike the government, it has limited influence over various policy arenas. To address labour supply and reduce recruitment and training costs for the BPO segment, NASSCOM has introduced a certification programme for building frontline managers in response to the 'managerial bandwidth' problem. Managed by NASSCOM's executive development programme and QAI (the leading 'quality' consultancy in India), they offer industry relevant certifications (e.g. Certified BPO Quality Analyst, Certified BPO Team Leader, Level 1), which have become popular among participants as well as businesses. To identify the right talent pool for the industry, a new assessment tool, the National Assessment of Competence for the BPO industry ${ }^{x}$, has been developed that can be used to identify new talent pools in various parts of the country, but also provide the industry, universities, and governments with information regarding key training and development needs. NASSCOM's long-term strategy is also evidenced in its desire to start English-language training schools (Sengupta, 2006), given the industry's dissatisfaction with a whole host of labour market intermediary firms ${ }^{\mathrm{xi}}$, who have not been able to meet the industry's needs thus far. ${ }^{\text {xii }}$ Finally, NASSCOM has created a National Skills Registry-a centralised

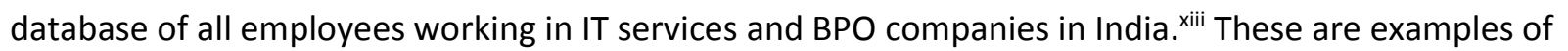
NASSCOM's initiatives (there are many more). NASSCOM's biggest achievement, however, is that it has managed (through a variety of methods) to put these issues on a slow-moving government's policy agenda.

Note, however, that high turnover and shortages of skilled labour is hurting the industry in terms of its ability to gain a greater market share and in terms of increasing costs. A 2007 NASSCOM report shows that the total cost to company for BPO associates who have been employed for six months to one year has gone up by 19 per cent in 2006 compared with just 3-4 per cent in 2005 . And employees leaving in the first 12 months are quite irksome, as many of them would have just completed their training (on average, training for voice-based processes takes roughly six to eight weeks). Thus, India's BPO firms are caught in the ironic position where India is the preferred BPO destination in the world ${ }^{\mathrm{xiv}}$ yet the labour shortage is making it difficult for India to further capitalise on this competitive advantage. 


\section{Conclusion}

This article briefly described the growth and associated HR problems of the business process segment of India's burgeoning outsourcing industry. The outsourcing industry (including software services) has come to be viewed as the 'primary engine of the country's development over the next few decades, contributing broadly to GDP growth, employment growth and poverty alleviation' (Srinivasan, 2006: 204). Within the outsourcing industry, the BPO segment has witnessed the fastest growth and will be larger than the much older software segment. The BPO segment is also growing in terms of diversity with increasingly variegated 'service lines' both at the high end (KPOs) and at the low end. The industry's growth prospects, however, are threatened by both high turnover and a shortage of suitably skilled personnel. At the high-end KPO firms (particularly in financial services, engineering services and life sciences), the problem is primarily a lack of a pipeline of adequately trained employees, especially for the longer-term development of the industry. For the lower-end BPOs, the problem is a shortage of English-speaking employees. Both ends of the industry are experiencing high turnover.

Although India has no dearth of managerial education and talent, the particular demographic profile of BPO employees is posing several challenges for managers. Established human resource practices that have been successful in building employee commitment and loyalty generally and in reducing attrition do not seem to work as effectively with this particular demographic group, and HR managers are experimenting with a variety of novel approaches.

The current global economic downturn has hit the BPO industry hard, especially for the large number of smaller firms in the business. This industry was growing at an annual average rate of 30 per cent prior to the slowdown, but growth rates in 2009 are hovering at about 15-18 per cent. The slowdown has resulted in considerable 'resizing', that is, many smaller companies have laid off people. Large companies have slowed recruitment, and many have temporary hiring freezes in place, but on the whole are still expanding, as more and more work gets offshored during this slowdown. The average turnover rate in BPO firms has reduced by about 6-7 per cent (NASSCOM). Yet industry experts remain very positive regarding the industry's growth prospects and predict high growth rates after 2011. Thus, despite the temporary respite, the problem of high turnover is bound to return. Therefore, future research must inquire more formally into the effectiveness of different strategies to reduce turnover for this demographic group in the Indian labour market. 


\section{References}

Batt, R., V. Doellgast, H. Kwon, M. Nopany, P. Nopany and A. da Costa (2006), The Indian Call Centre Industry: National Benchmarking Report Strategy, HR Practices, \& Performance, CAHRS Working Paper \#05-07 (Ithaca, NY, Cornell University, School of Industrial and Labor Relations, Center for Advanced Human Resource Studies), http://digitalcommons. ilr.cornell.edu/cahrswp/7.

D’Cruz, P. and E. Noronha (2006a), 'Being Professional: Organizational Control in Indian Call Centers’, Social Sciences Computer Review, 24, 3, 342-361.

D’Cruz, P. and E. Noronha (2006b, 27 May), 'Organising Call Centre Agents: Emerging Issues', Economic and Political Weekly, Retrieved 27 February 2007 from http://www.epw. org.in

Deery, S. and N. Kinnie (2004), Call Centres and Human Resource Management (Hampshire, Palgrave Macmillan). Dossani, R. (2006), 'Origins and Growth of the Software Industry in India', in H. S. Rowen, W. F. Miller and M. G. Hancock (eds) Making IT: The Rise of Asia in High-Tech (Stanford, Stanford University Press) pp. 221-268.

Finegold, D. (1999), 'Creating Self-Sustaining High Skill Ecosystems', Oxford Review of Economic Policy, 15, 1, 6090.

InfotechOnline (2004), 'BPO Workers More Satisfied Now', Retrieved 10 November 2006 from http://infotech.indiatimes.com/articleshow/msid-919912.cms

KPMG (2004), 'Strengthening the human resource foundation of the Indian IT enabled services/IT industry' (Mumbai, KPMG).

Kuruvilla, S., C. Erickson and A. Hwang (2002), 'An Assessment of the Singapore Skills Development System: Lessons for Developing Countries', World Development, 30, 8, 1461- 1476.

Kuruvilla, S. and A. Ranganathan (2008), 'Economic Development Strategies and Macro and Micro Level Human Resource Policies: The Case of India's Outsourcing Industry', Industrial and Labor Relations Review, 62, 1, $39-72$.

Locke, R. M. (1996), 'Remaking the Italian Economy' (Ithaca, Cornell University Press).

Menon, S., S. Sinha and A. Urs (2004, 1 August), 'Tug of Talent', The Economic Times, 7-8.

Mitra, P. (2004), 'Boom Boom BPO', The Telegraph, December 15.

NASSCOM (National Association of Software and Services Companies) (2003), NASSCOM Strategic Review 2003 (New Delhi, NASSCOM).

NASSCOM (National Association of Software and Services Companies) (2006), NASSCOM Strategic Review 2006, http://www.nasscom.org/Nassscom/templates/LandingPage.aspx ?id=4946.

NASSCOM (National Association of Software and Services Companies) (2007), NASSCOM Strategic Review 2007 (New Delhi, NASSCOM).

Pradhan, J. and V. Abraham (2005), 'Social and Cultural Impact of Outsourcing: Emerging Issues from Indian Call Centres', Harvard Asia Quarterly, Summer pp. 1-11. 
Ranganathan, A. and S. Kuruvilla (2007), 'Managing Low Skilled Employees in a High Tech Environment: Human

Resource Practices in India's Outsourcing Industry', in D. Jemelniak and J. Kociatkiewicz (eds),

Management Practices in High Tech Environments (New York, Information Science Reference) pp. 110-113.

Remesh, B. P. (2004), 'Cyber Coolies' in BPO: Insecurities and Vulnerabilities of Non-Standard Work', Economic and Political Weekly, January 31, pp. 492-497.

Saxenian, A. (2000), 'Bangalore: The Silicon Valley of Asia?’ Retrieved from http://www.

people.ischool.berkeley.edu/ anno/papers/bangalore_svasia.html

Sengupta, S. (2006), 'Skills Gap Hurts Technology Boom in India', New York Times, Technology Section, October 17.

Shrinate, S. (2004, 6 June), 'Truly, a Learning Experience', Business Today, 156-157.

Srinivasan, T. N. (2006), 'Information Technology and India's Growth Prospects', in L. Brainard and S. M. Collins (eds), Offshoring White-Collar Work-The Issues and Implications, The Brookings Trade Forum, 2005 (Washington, DC, The Brookings Institution) pp. 203-240.

Taylor, P. and P. Bain (2005), 'India Calling to The Far Away Towns': The Call Centre Process and Globalization', Work, Employment and Society, 19, 2, 261-282.

The Economic Times (2006), 'BPOs' No-Poaching Pacts Fall Apart', Retrieved 26 November 2006 from http://economictimes.indiatimes.com/BPOs_nopoaching_pacts_fall_apart/articleshow/498749.cms

The Economic Times (2007), 'How to Bell the BPO Cat', Retrieved 10 March 2007 from

http://economictimes.indiatimes.com/articleshow/msid-1736650,prtpage-1.cms

List of Companies Interviewed: 2007

1. LaserWords

2. Microland

3. Prodapt

4. Infosys BPO

5. TakeSolutions

6. GAVS

7. SSI

8. Infosys

' For a more detailed study of policy responses, see Kuruvilla and Ranganathan (2008).

ii Note that the term 'outsourcing industry' refers to software services, hardware, research and development services, and business process outsourcing (also called ITES-BPO) by the industry association (NASSCOM), which is the only reliable source of data on the outsourcing industry.

iii A 'captive' BPO firm is one that is wholly owned by the client firm and provides services to only that firm ... essentially it is like a separate 'in-house' operation. American Express, for example, has its own captive firm in India doing its back-office work. A 'third-party' firm is one that provides services to a multitude of clients. Infosys's BPO firm (formerly called Progeon) is one such example. In general, 'captives' have a more stable market for their services relative to 'third-party' firms. 
iv One example of the difficulty of making estimates in this rapidly growing industry (and of using the past as a basis for future predictions) can be seen in the experience of the last two years. In 2003-04, the BPO industry added 55,000 jobs. At that time, NASSCOM predicted that over the next two to three years, the industry would grow by about 55-70,000 jobs. But in the next year alone (2004-05), 95,000 jobs were added.

${ }^{~ N A S S C O M ' s ~ e s t i m a t e s ~ a r e ~ t h a t ~} 1.416$ million workers would be required. Productivity increases would reduce this figure by about 413,000 , leaving 1.003 million. The expected supply by 2009 is 741,000 leaving a projected shortfall of 262,000 .

vi The absence of figures stems from the division of responsibility in the education sector of India. For one, this sector is on the 'concurrent' list, which means that it falls under the jurisdiction of central and state governments (Dossani, 2006). In addition, several states permit the private sector to operate schools and colleges. And there is no central statistics agency that covers all these sectors.

vii It is important to note that several things could mitigate the shortfall. For one, the number of English speaking graduates could increase as more and more attention is paid to spoken English in educational institutions and private training institutes. Second, it is possible that graduates who have not been attracted to this industry will be motivated to join in the future, especially given the growth in salaries. Finally, the number of educational institutions may increase, consistent with prior trends, although it is unclear as to where the faculty are coming from (there is a shortage of faculty). In fact, the number of private training institutes claiming to provide training for the BPO industry has grown dramatically over the last few years.

viii Note that the governments have done considerably more for the software industry. Two state governments (Andhra Pradesh and Karnataka) have opened well-funded new institutes of IT to supply more graduates to the high-end software industry. The central government has been slower to respond but has recently established a nodal agency at the national level called Consortium for Indian Information Technology Education, which is supposed to coordinate and standardise education in the IT arena, and has already established two more Indian Institute of Technology and has agreed to finance one more Institute for Science.

ix Obviously large-scale reform in public universities is necessary because almost every dimension of higher education needs change. Financial issues and pay of professors and research associates are particularly low. As a matter of interest the gross monthly salary for a senior professor at the IITs is roughly $\$ 675$ per month, not very different from what his or her student would earn at an entry-level job in the high-tech industry. While professors are allowed to consult (they retain 65 per cent of the revenues), not many professors do the cuttingedge research that provides consultancy opportunities.

${ }^{x}$ The programme will test the aptitude of a candidate on seven different skill sets. This includes listening and keyboard skills, verbal ability, spoken English, comprehension and writing ability, office software usage, numerical and analytical skills, and concentration and accuracy.

xi Hero Mindmine, Akiko Callnet, Planetworkz (NIIT) that seek to provide trained people to the BPO industry.

xii However, interviews with BPO HR managers suggest that the quality provided is highly variable: some firms tell me that they only take in one out of five people provided by the intermediary firms. The problem is that the intermediary firms have not developed a consistent set of standards that they can use to meet the needs of the BPO firms.

xiii This database contains third-party verified personal, qualification, and career information of IT professionals and thus helps improve recruitment practices (and reduces recruitment costs) in the IT and BPO industry. Prospective employers are also able to view the verified resumes of IT professionals.

xiv India's leadership position is best demonstrated by the consulting firm AT Kearney's comprehensive evaluation tool developed to help corporations with their offshore location strategies. Their analysis indicates that India has a clear and significant lead over its major competitors, particularly with regard to the dimensions of costs and the quantity and quality of skills. India's score on their index is a 7.12, while all of the other BPO competitors (China, Malaysia, Czech Republic, Singapore, Philippines, Canada, Chile and Poland) scores range from 5.33 to 5.61. For a more detailed discussion of the methodology, see http://Knowledge.wharton.upenn.edu/article/922.cfm 